Bangladesh J. Bot. 49(4): 937-947, 2020 (December)

\title{
CHARACTERISTICS AND ANTIBIOGRAM OF AIRBORNE BACTERIAL COMMUNITIES
}

\author{
Md Abdul Karim* and Mehedi Al Masum \\ Department of Botany, University of Dhaka, Dhaka-1000, Bangladesh \\ Keywords: Airborne bacterial composition, Antibiogram, Seasonality
}

\begin{abstract}
Composition and concentration of the bacterial communities in air of using a culturedependent plate exposure technique and air sampling with filter were analysed. An average value of $2.8 \times 10^{3}$ bacterial $\mathrm{CFU} / \mathrm{m}^{3}$ was found in different seasons. A total of 8 bacterial genera were identified among 58 species. The most predominant bacteria were Bacillus (73\%), Planococcus (9\%), Staphylococcus (6\%), Micrococcus (4\%), Deinococcus (2\%), Arthrobacter (2\%), Microbacterium (2\%), and Exiguobacterium (2\%). The distribution of predominant airborne bacteria varied greatly between different sampling sites and seasons and was limited by environmental parameters, as well as human activities.
\end{abstract}

\section{Introduction}

Many environments contain diverse communities of microorganisms (Aziz 2018). The atmosphere is the main vehicle for the transportation and dispersion of microorganisms (Nugari et al. 1993). Constituents of the bioaerosol in the atmosphere may originate from both the natural and anthropogenic sources, including vegetation and soil (Lighthart 1998), vegetables (Lindemann 1985), animal feeding (Wilson et al. 2002), and traffic (Wu et al. 2007). Airborne microorganisms are crucial components of the atmosphere, with bacterial cells exceeding $1 \times 10^{4} \mathrm{~m}^{-3}$ (Burrows et $a l$. 2009), and they can threaten human health by disseminating allergens and pathogens (Griffin 2007). Many workers have investigated structural variation in the airborne bacterial community during haze events (Zhen et al. 2017, Du et al. 2018, Sun et al. 2018, Yan et al. 2018). Investigations have focused more and more on the ecological, environmental, and climatological effects of microbiology in air (Tong 2000, Rosenfeld et al. 2019). The air is often considered as an important carrier medium for bacterial pathogens, such as Streptococcus pneumoniae, S. pyogenes, Mycoplasma pneumoniae, Haemophilus influenzae, Klebsiella pneumoniae, Pseudomonas aeruginosa and Mycobacterium tuberculosis (Richards et al. 1999). To manage outdoor pathogens, it is important to understand and identify their source, survival, dispersal, and relation to the environment, in addition of these more information on the detection, monitoring, and transportation of bacterial pathogens in the atmosphere need to be considered also (Kuske 2006, Lai et al. 2009). Indoor and outdoor airborne bacterial community types changed independently of haze events, and the special airborne bacterial community type was closely related to the incidence of pneumonia in the heavy hazy season (Guo et al. 2020).

Dusts are the most common carriers of microorganisms that could be explored in the environment depending on the air movement and concentration of dust particles. Ambient air pollution contributed substantially to the global burden of disease in 2015, which increased over the past 25 years, due to population ageing, changes in non-communicable disease rates, and increasing air pollution in low- and middle-income countries. Modest reductions in burden will

*Author for correspondence: <makarim10@ gmail.com>. 
occur in the most polluted countries unless $\mathrm{PM}_{2.5}$ values are decreased substantially, but there is potential for substantial health benefits from exposure reduction (Cohen et al. 2017). According to UN statistics, level of dust in the air in Dhaka is one of the highest of the world. Common people are the worst victims as they must go out for work and many of them work outdoors. Airborne microorganisms in the Dhaka city are extremely important because of the economic and health problems. Thus the present study was conducted for the characterization and antibiogram of bacterial diversity in air spaces of Dhaka city.

\section{Materials and Methods}

Dhaka a mega city and one of the major cities of South Asia is located in central Bangladesh at $23^{\circ} 42^{\prime} 0^{\prime \prime} \mathrm{N} 90^{\circ} 22^{\prime} 30^{\prime \prime} \mathrm{E}$, on the eastern banks of the Buriganga river, Dhaka, along with its Metropolitan area, with a population of 20.28 million in 2019 and making it the largest city in Bangladesh (BBS 2019). With a density of 47,400 people per square kilometer, Dhaka remained the most densely populated city on earth for the third consecutive year and it has ranked the second least livable city in the world, according to the Economist Intelligence Unit's annual global survey (Amin 2018).

Samples were collected from seven different sampling sites of the Dhaka metropolis, viz., Hazrat Shahjalal International Airport, Gulshan-2 circle, Farmgate bus stand, Dhaka Medical College and Hospital (DMCH), Curzon Hall University of Dhaka, Railway Station, Kamlapur, and Sadarghat Launch Terminal. Global Positioning System (GPS) tracks satellites orbiting the earth to calculate precise location. This is done often through means of a handheld, portable Apple iphone 10S (USA), which monitors the satellites to determine exact latitude and longitude.

Two different techniques viz., exposure plate technique and membrane filtration technique were used for the enumeration and isolation of microorganisms from free air spaces. Air sampler (BK-G2.5, Ambient air sampler, Bulgaria) was used to collect the sample from different sampling sites and air was passed through the filter for two minutes. Prior to sampling, the instruments were placed on the ground level with their membrane filter paper holder about 1.5 meters above the ground level. The air passed through the filter sampler (Z269360, USA) was set to $0.029 \mathrm{~m}^{3}$ per minute average on the Petri dishes containing two different media viz., nutrient agar medium and plate count agar which were used for the enumeration and isolation of aerobic heterotrophic bacteria corresponding to filter collection of airborne particles (Atlas 2010). Exposure plate technique was used for the enumeration and isolation of bacteria (Sharp and Lyles 1969). All the culture plates were marked with sample name and incubated at $37^{\circ} \mathrm{C}$ for $48 \mathrm{hrs}$. Bacterial colonies were counted by a digital colony counter (DC-8 OSK 100086, Kayagaki, Japan). Discrete bacterial colonies were transferred onto nutrient agar slants. During this investigation, a total 46 out of 350 isolates from nutrient agar medium were randomly selected and purified for detailed identification.

After incubation, the number of colonies forming units (CFUs) on each culture plate was counted. For each sample, the average CFU was calculated from the duplicate plates, and the standard deviation was found. The average CFU values and the standard deviations found were converted to concentrations per $\mathrm{m}^{3}$ air, by multiplying with the dilution factor and dividing by the amount of collected air (Fang et al. 2007).

$$
\mathrm{CFU} / \mathrm{m}^{3} \text { air }=(\text { Average } \mathrm{CFU} \times 200) /\left(120 \times 0.3 \mathrm{~m}^{3} \text { air }\right)
$$

CFUs on each plate were enumerated, and bacterial concentrations were expressed as CFU per cubic meter of air $\left(\mathrm{CFU} / \mathrm{m}^{3}\right)$. Thirty-eight bacterial colonies from the samples were identified using conventional methods by Bergey's manual of systematic bacteriology II (Sneath et al. 1986) 
and Bergey's manual of determinative bacteriology (Holt et al. 1994), and eight isolates were identified by $16 \mathrm{~S}$ rRNA gene sequencing.

All the bacterial isolates were cultured in LB agar to grow single colony and one colony for each was resuspended in $50 \mu \mathrm{l}$ sterile miliQ water and subject to heat lysis by heating at $100^{\circ} \mathrm{C}$ water bath for 5 mins. The lysed cell suspension was centrifuged for 1 min at $13000 \mathrm{rpm}$ in microcentrifuge and then the supernatants were used as the source of template DNA for PCR amplification of $16 \mathrm{~S}$ rRNA gene. It was stored at $-20^{\circ} \mathrm{C}$ for further use.

The primer of following sequences CC [F] 5'- CCAGACTCCTACGGGAGGCAGC and CD [R] 3'-CTTGTGCGGGCCCCCGTCAATTC were used for the partial amplification of 16S rRNA gene and for automated sequencing (Moghaddam et al. 2018). Added $25 \mu 1$ volume master mixture in the oil free thermal cycler (UNO II, Biometra) contain PCR buffer, dNTPs, Tag DNA polymerase, sterile miliQ water, primers, and template DNA. The amplifications were repeated 30 times for initial denaturation $5.0 \mathrm{mins}$ at $95^{\circ} \mathrm{C}$, denaturation $1.0 \mathrm{~min}$ at $94^{\circ} \mathrm{C}$, primer annealing 30.0 seconds at $55^{\circ} \mathrm{C}$, polymerization $1.0 \mathrm{~min}$ at $72^{\circ} \mathrm{C}$, final extension $10.0 \mathrm{~min}$ at $72^{\circ} \mathrm{C}$ and the final product was stored at $4^{\circ} \mathrm{C}$ for further process. The PCR product was run in $1.0 \%$ agarose gel electrophoresis under UV light after ethidium bromide staining (Borst 2005). DNA bands were observed on UV-transilluminator and photographed by a Gel Documentation system (Microdoc DI-HD, MUV2I-254/365, Cleaver Scientific, UK). The amplified bands were gel purified using Gel purification kit (Invitrogen) and sequenced from Macrogen, South Korea.

The isolates were identified based on alignment of partial sequence of 16S rRNA gene with the existing sequences available in the database. The sequence generated from automated sequencing of PCR amplified DNA was analyzed through NCBI-BLAST (http://blast.ncbi. nlm.nih.gov/blast.cgi) and rRNA BLAST (http://bioinformatics.psb.ugent.be/cgi-bin/rRNA/ blastform.cgi) programs to find out possible similar organisms in the databases. A phylogenetic tree of the isolates was generated using neighbor joining (NJ) distance-based algorithm of phylogenetic analysis (Saitou and Nei 1987). Sequences obtained from BLASTN (nucleotide blast) were in FASTA format and relation between each sequence could be known by multiple sequence alignment using Clustal Omega (http://www.ebi.ac.uk/Tools/msa/clustalo/). The data were analyzed to determine the descriptive statistics viz., statistical mean and standard deviation (Sd) with SPSS v.16.0 for Windows (SPSS, SAS Institute Inc. Cary, USA).

The selected isolates were grown in different flasks containing media with various initial $\mathrm{pH}$ $(4.5,5.5,6.5,7.5$ and 8.5$)$ at $37^{\circ} \mathrm{C}$ and at various cultivation temperature $(5,10,30,40,50,55$, and $65^{\circ} \mathrm{C}$ ) maintaining initial $\mathrm{pH}$ of the medium at 7.0 to check the optimum $\mathrm{pH}$ and temperature for growth, respectively.

Antibacterial sensitivity test with gentamycin (CN 120), streptomycin (S 10), penicillin G (P 10), polymyxin B (PB 300), neomycin (N 30), vancomycin (VA 30) and rifampicin (RD 5) against the selected isolate was carried out for their ability to grow in the presence of different antibiotics at concentration selected for diagnostic value. The filter paper disks placed on the surface of Muller Hinton agar plates inoculated with $0.1 \mathrm{ml}$ of bacterial suspension (Atlas 1997). Inoculated plates incubated at $37^{\circ} \mathrm{C}$ for $24 \mathrm{hrs}$. Development of a clear zone around the disk indicated sensitivity, while antibiotic disk without clear zone indicated resistance to the antibiotic.

\section{Results and Discussion}

'Sampling sites location measured by the GPS technique and are presented in Table 1. Considering the cultural, morphological and biochemical characteristics of the bacterial isolates, provisional identification was made for 38 isolates (Table 2). All 38 isolates were Gram-positive, of which 30 were under the genus Bacillus and the others were under the genus Planoccoccus, 
Staphylococcus and Micrococcus (Table 3). Under the genus Bacillus, the provisionally identified species were B. subtilis (6), B. alvei (6), B. brevis (5), B. firmus (3), B. stearothermophilus (3), B. alcalophilus (2), B. pumilus (2), B. cereus, B. macerans and B. panthothenticus (Table 3).

Table 1. GPS reading of sampling sites.

\begin{tabular}{lcc}
\hline Sampling sites & North & East \\
\hline Hazrat Shahjalal International Airport & $23^{\circ} 05^{\prime} 53^{\prime \prime}$ & $90^{\circ} 24^{\prime} 18^{\prime \prime}$ \\
Curzon Hall & $23^{\circ} 43^{\prime} 39^{\prime \prime}$ & $90^{\circ} 24^{\prime} 48^{\prime \prime}$ \\
Dhaka Medical College and Hospital (DMCH) & $23^{\circ} 43^{\prime} 35^{\prime \prime}$ & $90^{\circ} 23^{\prime} 54^{\prime \prime}$ \\
Farmgate bus stand & $23^{\circ} 45^{\prime} 28^{\prime \prime}$ & $90^{\circ} 23^{\prime} 28^{\prime \prime}$ \\
Gulshan circle-2 & $23^{\circ} 47^{\prime} 42^{\prime \prime}$ & $90^{\circ} 24^{\prime} 51^{\prime \prime}$ \\
Kamalapur Railway Station & $23^{\circ} 43^{\prime} 57^{\prime \prime}$ & $90^{\circ} 24^{\prime} 52^{\prime \prime}$ \\
Sadarghat Lunch Terminal & $23^{\circ} 42^{\prime} 21^{\prime \prime}$ & $90^{\circ} 24^{\prime} 23^{\prime \prime}$ \\
\hline
\end{tabular}

The rest 8 isolates were identified as Bacillus megaterium Y18-10, Micrococcus luteus, Arthrobacter nicotianae YNA111, Microbacterium esteraromaticum, Bacillus thuringiensis RUNI, Exiguobacterium arabatum 27CpOI17 and Bacillus cereus MSSRFS78, Bacillus thuringiensis RUNI based on sequence analysis (Table 4).

A phylogenetic tree of the 8 isolates was generated using neighbor joining (NJ) distancebased algorithm (Fig. 1). It was detected that there was only one cluster comprising of two subclusters. These sub-clusters grouped Bacillus cereus along with Micrococcus luteus, Arthrobacter nicotianae and Microbacterium esteraromaticum in one cluster and Exiguobacterium arabatum in other. On the other hand, there were also two small sub clusters completely comprised of Bacillus thuringiensis. This observation suggested the evolutionary divergence of these bacteria indicated their evolutionary trend.

The most prevalent bacterial genera are presented in Fig. 2. Significantly higher variation of the genera Staphylococcus, Bacillus, Micrococcus, Microbacterium and Arthrobacter were detected in Hazrat Shahjalal International Airport (30\% of Staphylococcus, 20\% of Bacillus, 20\% of Planococcus and 10\% of each genera of Microbacterium and Arthrobacter) than those in the other six sites (Tables 3,4). The proportion of Bacillus in the Curzon Hall, Dhaka Medical College Hospital and Farmgate bus stand was 66.67, 75 and 60\%, respectively, while it was $100 \%$ in the Gulshan-2 circle, Kamalapur Railway Station and Sadarghat Launch Terminal, respectively (Tables 3, 4). In the Farmgate bus stand Planococcus was $40 \%$ and Exiguobacterium was 25\% in the Dhaka Medical College Hospital. High light intensity, extreme temperature variations, low amount of organic matter and a scarcity of available water making is a non-hospitable environment for microorganisms and generally unsuitable habitat for their growth. Nevertheless, substantial numbers of microbes are found in the lower regions of the atmosphere (Van Houdt et al. 2009). Among the bacteria detected in the atmosphere, the majority is Gram-positive, and many are spore-formers viz., Bacillus spp. and Microbacterium spp. were particularly dominant in the air during a dust event (Kellogg and Griffin 2006). High microbial diversity (25 genera, 56 species), with a dominant community including Staphylococcus, Bacillus, Acinetobacter and Kocuria, was found by the cultivation-based method (Wu et al. 2018).

Selected bacterial isolates were allowed to grow within a varied range of temperature 5 $65^{\circ} \mathrm{C}$; of which $40^{\circ} \mathrm{C}$ was most preferred by all isolates, while A5, S4, S5 and S8 showed highest growth at $50^{\circ} \mathrm{C}$ and isolates $\mathrm{A} 2, \mathrm{C} 3$ and $\mathrm{R} 4$ can grow even at $60^{\circ} \mathrm{C}$ (Fig. 3). It was found that almost all isolates grew well at $\mathrm{pH}$ ranging from 4.5 to 8.5 , but $\mathrm{pH} 6.5$ was preferred by most of the isolates (Fig. 4). Out of 46 isolates, 17 viz., A4, A6, A7, A9, A10, D2, D3, D4, F1, F2, 


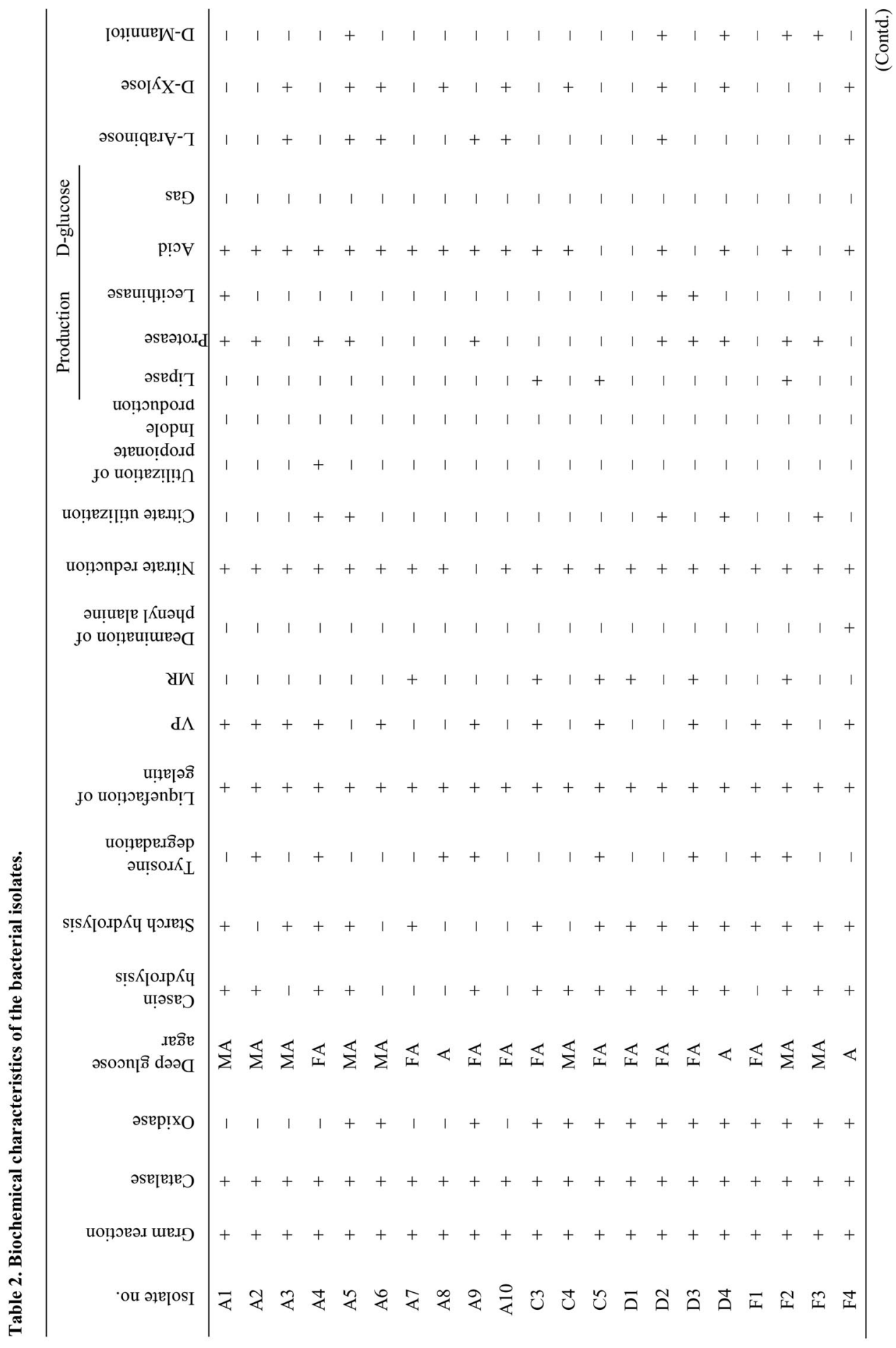




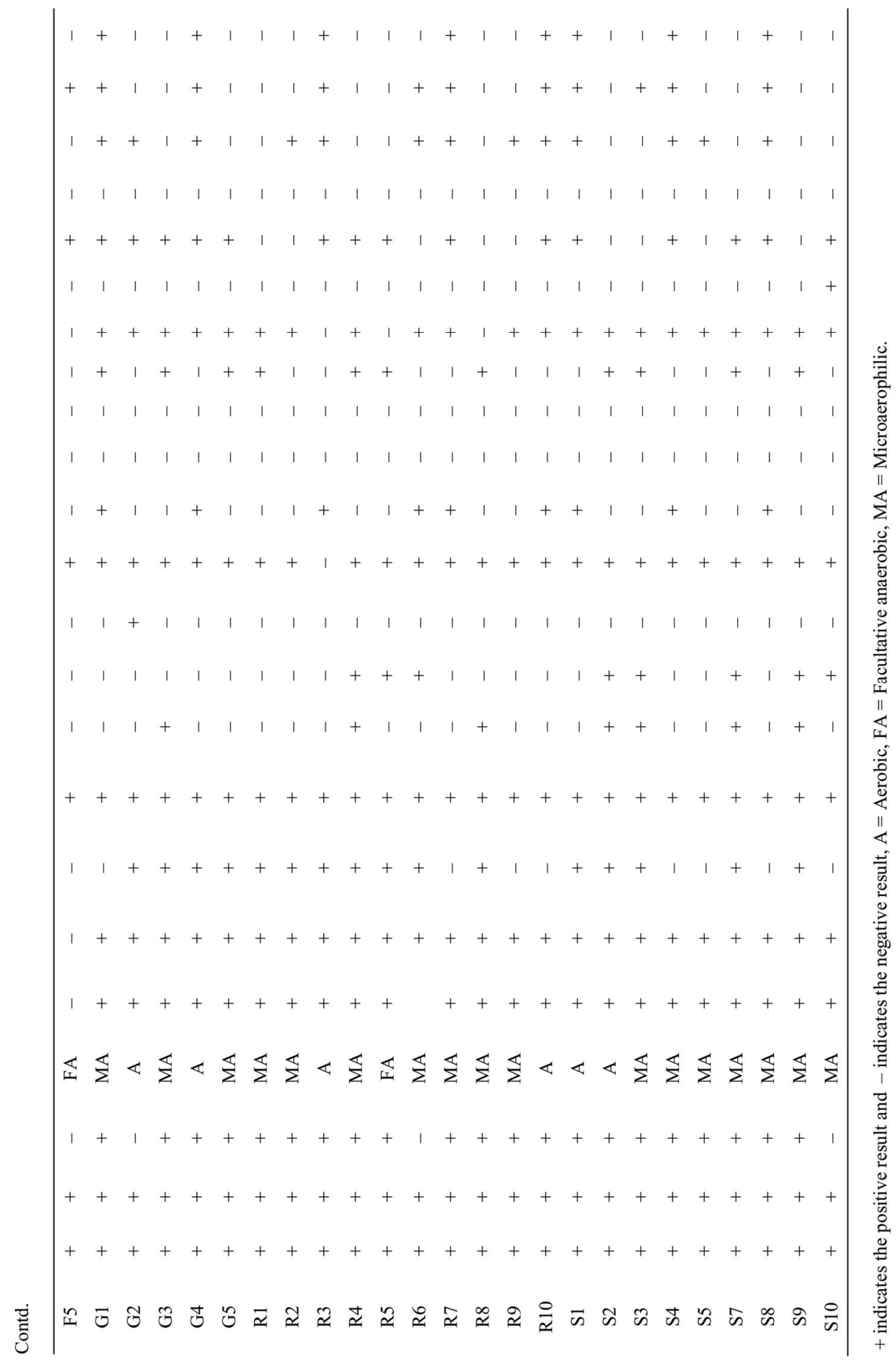


G2, R2, S1, S2, S4, S7 and S9 grew well at $\mathrm{pH} 7.5$ than $\mathrm{pH} 6.5$, while A9, F1, R3 and S2 were found to be alkalophilic in nature and grew well at $\mathrm{pH} 8.5$ and G1 and R7 were found to be slightly acidophilic and grew well at pH 5.5 (Fig. 4).

Table 3. Provisional identification of the selected heterotrophic isolates.

\begin{tabular}{|c|c|c|c|}
\hline $\begin{array}{c}\text { Isolate } \\
\text { no. }\end{array}$ & $\begin{array}{l}\text { Provisionally } \\
\text { identified names }\end{array}$ & $\begin{array}{c}\text { Isolate } \\
\text { no. }\end{array}$ & $\begin{array}{l}\text { Provisionally } \\
\text { identified names }\end{array}$ \\
\hline A3 & Planococcus sp. & G5 & Bacillus brevis \\
\hline A4 & Staphylococcus sp. & $\mathrm{R} 1$ & Bacillus firmus \\
\hline A5 & Bacillus stearothermophilus & $\mathrm{R} 2$ & Bacillus brevis \\
\hline A6 & Planococcus sp. & R3 & Bacillus pumilus \\
\hline A7 & Staphylococcus sp. & R5 & Bacillus subtilis \\
\hline A9 & Staphylococcus sp. & R6 & Bacillus macerans \\
\hline $\mathrm{C} 4$ & Micrococcus sp. & R7 & Bacillus brevis \\
\hline $\mathrm{C} 5$ & Bacillus subtilis. & $\mathrm{R} 8$ & Bacillus alvei \\
\hline D2 & Bacillus alcalophilus & R9 & Bacillus subtilis \\
\hline D3 & Bacillus pumilus & $\mathrm{R} 10$ & Bacillus stearothermophilus \\
\hline D4 & Bacillus cereus & $\mathrm{S} 1$ & Bacillus brevis \\
\hline $\mathrm{F} 1$ & Planococcus sp. & $\mathrm{S} 2$ & Bacillus alvei \\
\hline $\mathrm{F} 2$ & Bacillus firmus & S3 & Bacillus alvei \\
\hline $\mathrm{F} 3$ & Bacillus brevis & S4 & Bacillus subtilis \\
\hline F5 & Planococcus sp. & S5 & Bacillus alcalophilus \\
\hline G1 & Bacillus stearothermophilus & S7 & Bacillus alvei \\
\hline $\mathrm{G} 2$ & Bacillus firmus & $\mathrm{S} 8$ & Bacillus subtilis \\
\hline G3 & Bacillus alvei & S9 & Bacillus alvei \\
\hline G4 & Bacillus subtilis & $\mathrm{S} 10$ & Bacillus pantothenticus \\
\hline
\end{tabular}

Table 4. Sequence based identification of the selected bacterial isolates using bioinformatics.

\begin{tabular}{|c|c|c|c|c|c|}
\hline \multirow{2}{*}{$\begin{array}{c}\text { Name of } \\
\text { the } \\
\text { isolates }\end{array}$} & \multicolumn{2}{|c|}{$\begin{array}{c}\text { Name and accession number of the bacterial isolates } \\
\text { having highest similarity }\end{array}$} & \multicolumn{3}{|c|}{$\begin{array}{l}\text { Basis of the bioinformatics } \\
\text { parameters }\end{array}$} \\
\hline & $\begin{array}{l}\text { Accession } \\
\text { number }\end{array}$ & $\begin{array}{l}\text { Scientific } \\
\text { name }\end{array}$ & Strain & $\begin{array}{l}\text { Max. coverage } \\
\text { score }\end{array}$ & $\begin{array}{l}\text { Identities } \\
\text { match }(\%)\end{array}$ \\
\hline A1 & HQ333020.1 & Bacillus megaterium & Y18-10 & 1002 & 99 \\
\hline A2 & HE587970.1 & Micrococcus luteus & - & 573 & 87 \\
\hline A8 & JQ071518.1 & Arthrobacter nicotianae & YNA111 & 965 & 99 \\
\hline A10 & AB646579.2 & Microbacterium esteraromaticum & - & 966 & 99 \\
\hline $\mathrm{C} 3$ & HQ873480.1 & Bacillus thuringiensis & RUN1 & 977 & 99 \\
\hline D1 & JN602236.1 & Exiguobacterium arabatum & 27CpOI17 & 845 & 94 \\
\hline $\mathrm{F} 4$ & HQ701803.1 & Bacillus cereus & MSSRFS78 & 211 & 92 \\
\hline $\mathrm{R} 4$ & HQ873480.1 & Bacillus thuringiensis & RUN1 & 998 & 99 \\
\hline
\end{tabular}

Total 20 isolates were susceptible to all antibiotics at different ranges (Table 5). Isolates A3, A6, G1 were resistant to streptomycin; A7, C3, C4, C5, D3, F2, F4, G3, R1, R2, R4, R5, R8, S2, S3, S5, S7 and S9 were resistant to penicillin G; A10 and S8 were resistant to polymyxin B; and G2 was resistant to rifampicin only. Two isolates G5 and R9 were resistant to both penicillin G and polymyxin B (Table 5). 


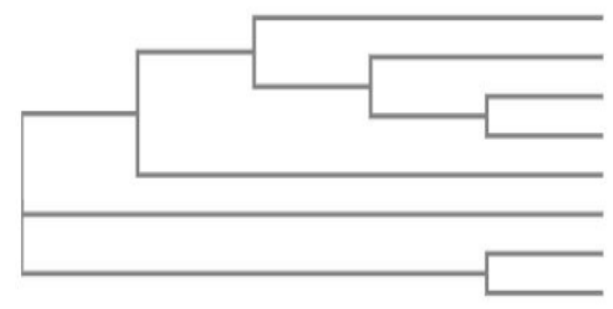

Bacillus cereus strain MSSRFS78

Micrococcus luteus

Arthrobacter nicotianae strain YNA111

Microbacterium esteraromaticum

Exiguobacterium arabatum strain 27CpOI17

Bacillus megaterium strain Y18-10

Bacillus thuringiensis strain RUN1

Bacillus thuringiensis strain RUN1

Fig. 1. Evolutionary relationships of the taxa. The evolutionary history was inferred using the NeighborJoining method (Saitou and Nei 1987).
围Bacillus
$\mathbf{8}$ Planococcus
日Staphylococcus
Micrococcus
mDeinococcus
DArthrobacter
-Microbacterium
Exiguobacterium

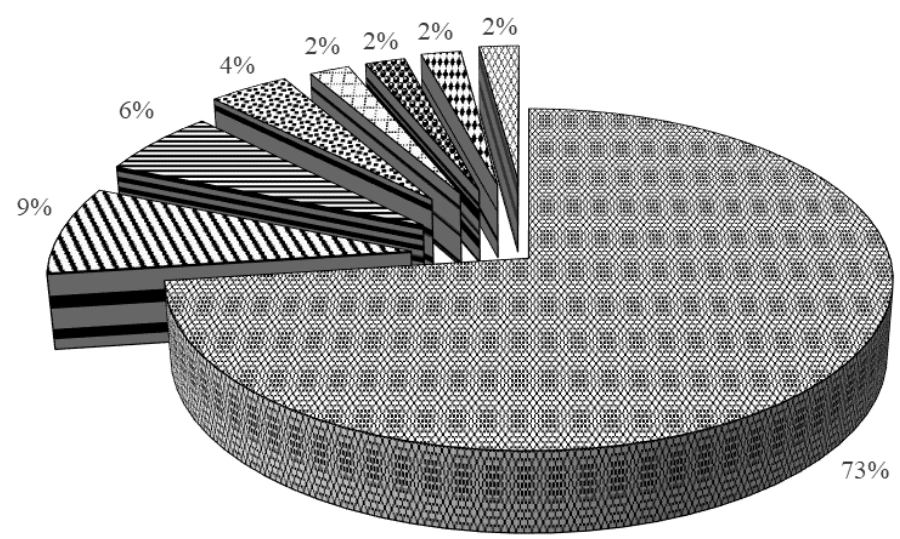

Fig. 2. Proportions of bacterial genera detected among the airborne bacterial community in the Dhaka city.

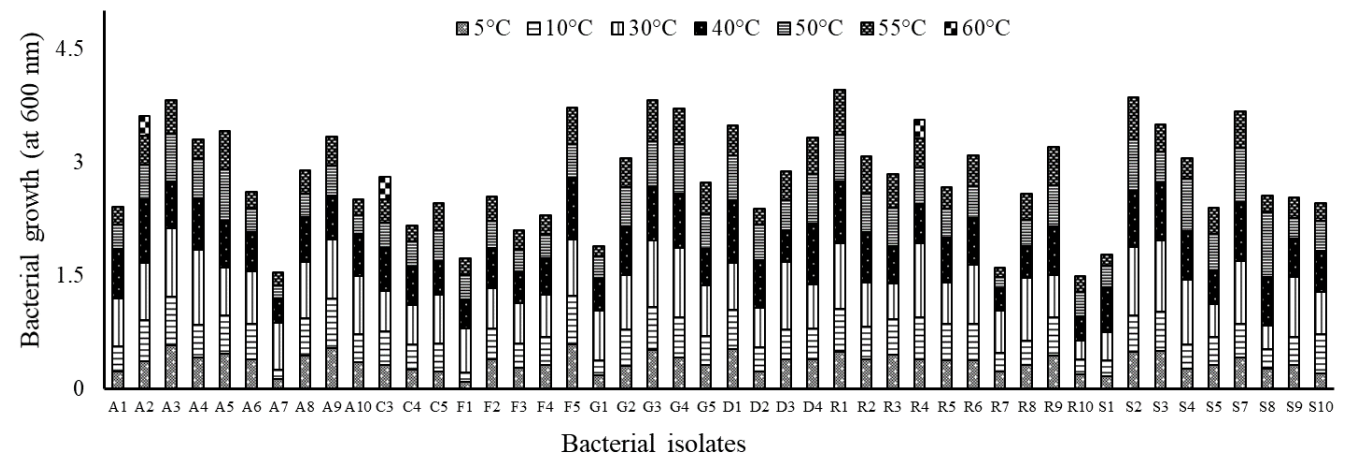

Fig. 3. Effects of temperature on bacterial growth. 
Table 5. Antibiogram of the selected isolates.

\begin{tabular}{|c|c|c|c|c|c|c|c|}
\hline \multirow{3}{*}{ Isolate no. } & \multicolumn{7}{|c|}{ Inhibition zone measured in diameter $(\mathrm{mm})$} \\
\hline & \multicolumn{7}{|c|}{ Name of the antibiotics } \\
\hline & $\mathrm{CN} 120$ & S 10 & $\mathrm{P} 10$ & PB 300 & N 30 & VA 30 & RD 5 \\
\hline Al & S (9) & $\mathrm{S}(12)$ & S (7) & $\mathrm{S}(10)$ & S (10) & S (14) & $S(6)$ \\
\hline A2 & $\mathrm{S}(11)$ & S (14) & $S(22)$ & $\mathrm{S}(6)$ & $S(17)$ & $\mathrm{S}(11)$ & S (27) \\
\hline A3 & $S(6)$ & $\mathrm{R}$ & $S(5)$ & $S(6)$ & $S(13)$ & $S(13)$ & $S(7)$ \\
\hline A4 & $S(10)$ & $S(14)$ & $\mathrm{S}(40)$ & $S(7)$ & $S(12)$ & $S(14)$ & $S(22)$ \\
\hline A5 & S (24) & $S(10)$ & $\mathrm{S}(25)$ & $S(6)$ & $S(21)$ & $\mathrm{S}(13)$ & S (23) \\
\hline A6 & $S(6)$ & $\mathrm{R}$ & S (7) & S (6) & S (11) & S (13) & $S(6)$ \\
\hline A7 & $S(12)$ & S (18) & $\mathrm{R}$ & S (9) & S (5) & S (8) & S (4) \\
\hline A8 & $S(15)$ & S (18) & S (40) & S (9) & $S(25)$ & $S(20)$ & S (29) \\
\hline A9 & S (13) & S (15) & S (28) & S (9) & S (17) & S (11) & S (26) \\
\hline $\mathrm{A} 10$ & $S(6)$ & $S(5)$ & $S(7)$ & $\mathrm{R}$ & $S(27)$ & $S(21)$ & S (4) \\
\hline $\mathrm{C} 3$ & S (11) & S (14) & $\mathrm{R}$ & S (3) & S (3) & S (9) & S (5) \\
\hline $\mathrm{C} 4$ & S (18) & S (14) & $\mathrm{R}$ & S (13) & $S(22)$ & S (18) & S (23) \\
\hline $\mathrm{C} 5$ & S (13) & S (14) & $\mathrm{R}$ & S (4) & S (15) & S (9) & S (4) \\
\hline D1 & S (11) & S (8) & S (28) & S (5) & S (5) & S (9) & S (13) \\
\hline D2 & $S(20)$ & S (14) & S (39) & S (6) & $S(22)$ & S (13) & S (24) \\
\hline D3 & $S(11)$ & S (16) & $\mathrm{R}$ & S (3) & S (14) & S (9) & $S(6)$ \\
\hline D4 & S (14) & S (19) & S (32) & S (6) & $S(16)$ & S (13) & S (29) \\
\hline $\mathrm{F} 1$ & S (16) & S (15) & S (14) & S (5) & S (18) & S (8) & S (13) \\
\hline $\mathrm{F} 2$ & $S(16)$ & S (25) & $\mathrm{R}$ & S (2) & S (14) & S (10) & S (8) \\
\hline F3 & $S(21)$ & S (13) & S (4) & S (8) & $S(21)$ & S (20) & S (10) \\
\hline F4 & S (13) & S (16) & $\mathrm{R}$ & $S(10)$ & S (19) & S (17) & S (11) \\
\hline F5 & S (4) & S (5) & S (7) & $S(10)$ & S (8) & S (7) & S (15) \\
\hline G1 & S (18) & $\mathrm{R}$ & S (38) & S (6) & $S(22)$ & S (14) & S (23) \\
\hline G2 & $S(10)$ & S (12) & S (10) & S (19) & S (17) & S (11) & $\mathrm{R}$ \\
\hline G3 & S (13) & S (11) & $\mathrm{R}$ & S (4) & S (14) & S (8) & S (3) \\
\hline G4 & S (18) & S (8) & S (7) & $S(6)$ & S (14) & S (16) & $S(7)$ \\
\hline G5 & S (14) & S (5) & $\mathrm{R}$ & $\mathrm{R}$ & S (8) & S (3) & S (7) \\
\hline $\mathrm{R} 1$ & S (13) & S (16) & $\mathrm{R}$ & S (3) & S (14) & S (10) & S (3) \\
\hline $\mathrm{R} 2$ & S (19) & S (10) & $\mathrm{R}$ & S (6) & S (17) & S (14) & S (11) \\
\hline R3 & S (14) & $S(12)$ & S (7) & S (6) & $S(25)$ & S (14) & $S(7)$ \\
\hline $\mathrm{R} 4$ & S (11) & S (12) & $\mathrm{R}$ & S (4) & S (15) & S (5) & S (3) \\
\hline R5 & S (13) & S (20) & $\mathrm{R}$ & S (3) & $S(16)$ & S (11) & S (6) \\
\hline R6 & S (14) & $S(16)$ & S (5) & S (7) & $S(2)$ & S (13) & S (9) \\
\hline R7 & S (23) & S (14) & S (46) & S (7) & $S(21)$ & S (13) & S (24) \\
\hline R8 & S (13) & S (15) & $\mathrm{R}$ & S (3) & S (15) & S (9) & S (4) \\
\hline R9 & S (20) & S (11) & $\mathrm{R}$ & $\mathrm{R}$ & S (16) & $S(14)$ & S (10) \\
\hline $\mathrm{R} 10$ & S (18) & S (10) & S (7) & S (7) & S (18) & S (13) & S (9) \\
\hline $\mathrm{S} 1$ & $S(25)$ & S (14) & S (8) & $S(11)$ & $S(25)$ & S (18) & S (8) \\
\hline S2 & $S(12)$ & S (13) & $\mathrm{R}$ & S (4) & $S(16)$ & S (11) & S (9) \\
\hline S3 & S (13) & S (14) & $\mathrm{R}$ & S (14) & S (14) & S (9) & S (3) \\
\hline S4 & S (15) & S (11) & S (3) & S (7) & $S(21)$ & S (14) & S (9) \\
\hline S5 & $S(21)$ & $S(12)$ & $\mathrm{R}$ & S (5) & S (15) & S (13) & S (11) \\
\hline S7 & $S(11)$ & S (11) & $\mathrm{R}$ & S (5) & $S(15)$ & S (5) & S (4) \\
\hline S8 & $S(20)$ & S (11) & S (23) & $\mathrm{R}$ & S (19) & S (13) & S (24) \\
\hline S9 & S (11) & S (11) & $\mathrm{R}$ & S (4) & S (16) & S (10) & S (3) \\
\hline $\mathrm{S} 10$ & $\mathrm{~S}(10)$ & S (16) & $\mathrm{S}(10)$ & S (8) & S (14) & $\mathrm{S}(13)$ & $\mathrm{S}(15)$ \\
\hline
\end{tabular}

S = Sensitive, R = Resistant, CN $120=$ Gentamycin, S $10=$ Streptomycin, P $10=$ Penicillin G, PB $300=$ Polymyxin B, N $30=$ Neomycin, VA $30=$ Vancomycin and RD $5=$ Rifampicin. 
The distribution of predominant airborne bacteria varied greatly between different sampling sites and seasons and was limited by environmental parameters, as well as human activities. The size distributions of bacteria during different sites also indicated the presence of different bacterial genera in the air. The predominant bacteria under the genus Bacillus, Planococcus, Staphylococcus, Micrococcus, Deinococcus, Arthrobacter, Microbacterium and Exiguobacterium were mainly distributed in the stages relating to trapping ranges.

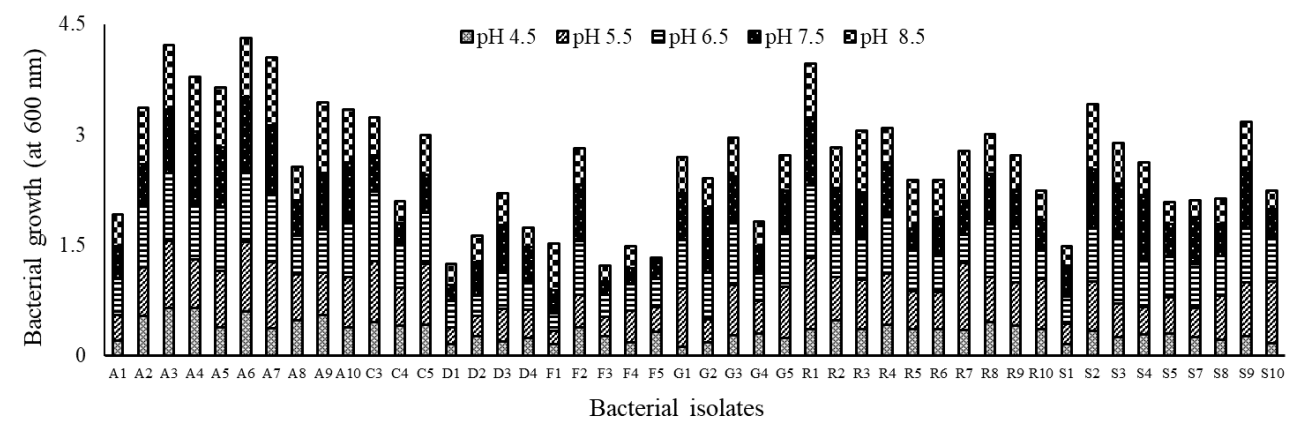

Fig. 4. Effects of $\mathrm{pH}$ on bacterial growth.

These results highlight the difficulty in understanding and interpreting the microbial structure of these communities, and consequently, more attention should be paid to the conservation of the city environment.

\section{Reference}

Aziz A Abd, Lee K, Park B, Park H, Park K, Choi IG and Chang IS 2018. Comparative study of the airborne microbial communities and their functional composition in fine particulate matter (PM2.5) under nonextreme and extreme PM2.5 conditions. Atmos. Environ. 194: 82-92.

Amin MA 2018. Dhaka remains the world's most densely populated city. Dhaka Tribune, October 14.

Atlas RM 1997. Microbiological Media ( $2^{\text {nd }}$ ed.). CRC Press. Inc. USA. p. 1706.

Atlas RM 2010. Handbook of Microbiological Media (4 ${ }^{\text {th }}$ Ed.). CRC press. Kentucky, pp. 10-2000.

Bangladesh Bureau of Statistics 2019. The metro area population of Dhaka in 2019.

Borst P 2005. Ethidium DNA Agarose Gel Electrophoresis: How it started. 57(11): 745-747.

Burrows SM, Elbert W, Lawrence MG and Poschl U 2009. Bacteria in the global atmosphere - Part 1: Review and synthesis of literature data for different ecosystems. Atmos. Chem. Phys. 9: 9263-9280.

Cohen AJ, Brauer M, Burnett R, Anderson HR, Frostad J, Estep K, Balakrishnan K, Brunekreef B, Dandona L, Dandona R, Feigin V, Freedman G, Hubbell B, Jobling A, Kan H, Knibbs L, Liu Y, Martin R, Morawska L, Pope 3rd CA, Shin H, Straif K, Shaddick G, Thomas M, van Dingenen R, van Donkelaar A, Vos T, Murray CJL and Forouzanfar MH 2017. Estimates and 25-year trends of the global burden of disease attributable to ambient air pollution: an analysis of data from the Global Burden of Diseases Study 2015. Lancet 389(10082): 1907-1918.

Du P, Du R, Ren W, Lu Z and Fu P 2018. Seasonal variation characteristic of inhalable microbial communities in PM2.5 in Beijing city, China. Sci. Total Environ. 610: 308-315.

Fang Z, Z Ouyang, H Zheng, X Wang and L Hu 2007. Culturable airborne bacteria in outdoor environments in Beijing, China. Microbial Ecology. 54(3): 487-496.

Griffin DW 2007. Atmospheric Movement of Microorganisms in Clouds of Desert Dust and Implications for Human Health. Clin. Microbiol. Rev. 20: 459-477.

Guo J, Xiong Y, Shi C, Liu C, Li H, Qian H, Sun Z and Qin C 2020. Characteristics of airborne bacterial communities in indoor and outdoor environments during continuous haze events in Beijing: Implications for health care Environ. Int. 139: 1-12. 
Holt JG, Krieg NR, Sneath PHA, Staley JT and Williams ST 1994. Bergey's Manual of Determinative Bacteriology (9th Ed.). Williams \& Wilkins, Baltimore, pp. 1-787.

Kellogg CA, Griffin DW 2006. Aerobiology and the global transport of desert dust. Trends Ecol. Evol. 21(11): 638-644.

Kuske CR, Barns SM, Grow CC, Merrill L and Dunbar J 2006. Environmental survey for four pathogenic bacteria and closely related species using phylogenetic and functional genes. J. Forensic. Sci. 51(3): 548-558

Lai KM, Emberlin J and Colbeck 2009. Outdoor environments and human pathogens in air. Environmental Health 8(Suppl 1): S15.

Lighthart B and Kirilenko A 1998. Simulation of summer-time diurnal bacterial dynamics in the atmospheric surface layer. Atmospheric Environment 32(14/15): 2491-2496.

Lindemann J and Upper CD 1985. Aerial dispersal of epiphytic bacteria over bean plants. Appl. Environ. Microbiol. 50(5): 1229-1232.

Moghaddam NM, Sabzevar HA, Zolfaghari RM and Lakzian 2018. Phenotypic and molecular characterization of Sinorhizobium meliloti strains isolated from the roots of Medicago sativa in Iran. Bio. J. Microorgan. 6(24): 29- 39.

Nugari MP, Realini M and Roccardi A 1993. Contamination of mural paintings by indoor airborne fungal spores. Aerobiologia 9(2): 131-139.

Richards MJ, Edwards JR, Culver DH, Gaynes RP 1999. Nosocomial infections in pediatric intensive care units in the United States. National Nosocomial Infections Surveillance System. Pediatrics 103: e39.

Rosenfeld D, Zhu Y, Wang M, Zheng Y, Goren T and Yu S 2019. Aerosol-driven droplet concentrations dominate coverage and water of oceanic low-level clouds. Science 363(6427), eaav0566: 1-9.

Saitou N and Nei M 1987. The Neighbor-joining Method: A New Method for Reconstructing Phylogenetic Trees. Mol. Biol. Evol. 4(4): 406-425.

Sharp MS and ST Lyles 1969. Laboratory Instruction in Biology of Microorganisms. Saint Louis the C V Mosley Company. pp. 23-25.

Sneath PHA, Mair NS, Sharpe ME and Holt JG (Eds.) 1986. Bergey's manual of systematic bacteriology (9th Ed.). Vol. 2. Williams and Wilkins, Baltimore, USA. 2: 1003-1139.

Sun Y, Xu S, Zheng D, Li J, Tian H and Wang Y 2018. Effects of haze pollution on microbial community changes and correlation with chemical components in atmospheric particulate matter. The Science of the total environment, 637-638: pp. 507-516.

Tong Y and Lighthart B 2000. The annual bacterial particle concentration and size distribution in the ambient atmosphere in a rural area of the Willamette Valley, Oregon. Aerosol Sci. and Technol. 32: 393-403.

Van Houdt R, P De Boever, I Coninx, C Le Calvez, R Dicasillati and J Mahillon et al. 2009. Evaluation of the airborne bacterial population in the periodically confined Antarctic Base Concordia. Microbial Ecology 57(4): 640-648.

Wilson SC, Morrow-Tesch J, Straus DC, Cooley JD, Wong WC and Mitlohner FM 2002. Airborne microbial flora in a cattle feedlot. Appl. Env. Microbiol. 68(7): 3238.

Wu YH, Chan CC, Rao CY, Lee CT, Hsu HH, Chiu YH et al. 2007. Characteristics, determinants, and spatial variations of ambient fungal levels in the subtropical Taipei metropolis. Atmospheric Environ. 41(12): 2500-2509.

Wu S, Jiang Y, Lou B, Feng J, Zhou Y, Guo L, Forsythe SJ and Man C 2018. Microbial community structure and distribution in the air of a powdered infant formula factory based on cultivation and high-throughput sequence methods. J. Dairy Sci. 101: 6915-6926.

Yan D, Zhang T, Su J, Zhao LL, Wang H, Fang XM, Zhang YQ, Liu HY, Yu LY 2018. Structural Variation in the Bacterial Community Associated with Airborne Particulate Matter in Beijing, China, during Hazy and Nonhazy Days. Appl. Environ. Microbiol. 84(9): e00004-18.

Zhen Q, Deng Y, Wang Y, Wang X, Zhang H, Sun X and Ouyang Z 2017. Meteorological factors had more impact on airborne bacterial communities than air pollutants. Sci. Total Environ. 601: 703-712. 